e ISSN-0976-7223 | Visit Us - www.researchjournal.co.in

DOI : 10.15740/HAS/IJAE/7.2/384-390

\title{
Enhancement of engineering characteristics by use of marble slurry in Udaipur region
}

\section{R.P. ARORA, N.K. AMETA AND KAPIL K. SAMAR}

Received : 03.04.2014; Revised : 17.08.2014; Accepted : 01.09.2014

See end of the Paper for authors' affiliation

Correspondence to :

\section{R.P. ARORA}

College of Technology and Engineering, Maharana

Pratap University of Agriculture and Technology, UDAIPUR (RAJASTHAN) INDIA

Email : rp45arora@yahoo.co.in
-ABSTRACT : : Marble powder is an excellent material for mechanical stabilization of cohesive soil. For proving this, various engineering tests were conducted with different soil samples of Udaipur region. Tested sample gave satisfactory results.

- KEY WORDS : Marble dust, Soil, Stabilization, CBR value, Permeability

ם HOW TO CITE THIS PAPER : Arora, R.P., Ameta, N.K. and Samar, Kapil K. (2014). Enhancement of engineering characteristics by use of marble slurry in Udaipur region. Internat. J. Agric. Engg., 7(2) : 384-390. 